\title{
Spatial and temporal variations of sediments in a subtropical microtidal estuary
}

\author{
Ileana ORTEGA', Lauro Júlio CALLIARI², Elaine Siqueira GOULART², \\ Leonir André COLLING ${ }^{3} \&$ Luiz Felipe Cestari DUMONT¹ \\ ' Laboratório de Crustáceos Decápodes, Universidade Federal do Rio Grande, Av. Italia Km 8, CEP 96201 - \\ 900, Rio Grande, RS, Brasil (ileanaortega@gmail.com, felipecdumont@gmail.com). \\ ${ }^{2}$ Laboratório de Oceanografia Geológica, Universidade Federal do Rio Grande Av. Italia Km 8, CEP 96201 - \\ 900, Rio Grande, RS, Brasil (Icalliari@log.furg.br, elainegoulart@gmail.com) \\ ${ }^{3}$ Laboratório de Ecologia de Invertebrados Bentônicos, Universidade Federal do Rio Grande, Av. Italia Km \\ 8, CEP 96201-900, Rio Grande, RS, Brasil (Icolling@furg.br).
}

\begin{abstract}
Sediment dynamics are determined by the synergy between the hydrodynamic condition and sediment properties. This study analyzed, between the years 2015-2017, the spatial and temporal changes in sediment texture of a shallow embayment in the Patos Lagoon estuary (Southern Brazil), and the influence of environmental parameters in these variations. Two areas were selected: an area more exposed to the estuary main channel dynamics and NE winds, and the other protected from them by islands. Each area was divided in shallow (mean depth $<2 \mathrm{~m}$ ) and deeper zones (mean depth $\geq 2 \mathrm{~m}$ ). The organic matter content presented a spatial and temporal variation, with maximum values higher than previously reported. Due to elevated rainfall rates during the winter and spring of 2015, higher values of fine sediments and organic matter were recorded, mainly at deeper zones. The protected area presented smaller grain sizes and their variability was correlated with wind speed and direction. While in the exposed area the water depth has a higher influence in the granulometric variations, decreasing grain sizes with depth increases. The higher seasonality in the granulometric variation was observed in the deeper zones, which presented the smaller grain sizes and lower values of asymmetry, decreasing these values in winter and spring. In conclusion, few centimeters in water depth may cause large changes in bottom types (or in the relative amount of sand, silt and clay) of shallow estuarine areas. From the environmental variables measured, wind, rainfall and bathymetry were the most influential in the temporal variation of the sediments, while hydrodynamic exposure on the spatial differences.
\end{abstract}

Keywords. Patos Lagoon, sedimentology, environmental factors, grain size

Resumo. VARIAÇÕES ESPACIAIS E TEMPORAIS DE SEDIMENTOS EM UM ESTUÁRIO SUBTROPICAL DE MICROMARÉ. A dinâmica sedimentar é determinada pela sinergia entre as condições hidrodinâmicas e as propriedades dos sedimentos. Este estudo analisou, entre 2015-2017, as mudanças espaço-temporais na textura sedimentar em uma enseada rasa do estuário da Lagoa dos Patos (Sul do Brasil), e a influência de parâmetros ambientais para estas variações. Duas áreas foram investigadas: uma mais exposta às dinâmicas do canal principal do estuário e aos ventos NE, e a outra protegida destes fatores por ilhas. Cada área foi dividida em zonas rasas (profundidade média $<2 \mathrm{~m}$ ) e zonas mais profundas (profundidade média $\geq 2 \mathrm{~m}$ ). 0 teor de matéria orgânica apresentou variações espaço-temporais, com valores máximos superiores aos previamente reportados. Devido às altas taxas de precipitação durante o inverno e primavera de 2015, nestes períodos foram encontrados os valores mais elevados de sedimentos finos e matéria orgânica nas zonas mais profundas. A área protegida apresentou menores tamanhos de grão e a sua variabilidade esteve correlacionada com a intensidade e direção do vento. Por outro lado, a profundidade da lâmina d'água exerceu maior influência nas variações granulométricas na área exposta, diminuindo os tamanhos de grão com o aumento da profundidade. A maior sazonalidade na variação granulométrica foi observada nas zonas mais profundas, as quais apresentaram os menores tamanhos de grão e menores valores de assimetria, diminuindo estes valores no inverno e primavera. Conclui-se que poucos centímetros de diferença na profundidade podem ocasionar grandes variações nos tipos de fundo (ou na porcentagem relativa de areia, silte e argila) de zonas rasas estuarinas. Dos parâmetros ambientais medidos, o vento, pluviosidade e batimetria são os mais influentes na variação temporal dos sedimentos, enquanto que a exposição à hidrodinâmica nas diferenças espaciais.

Palavras-chave. Lagoa dos Patos, sedimentologia, fatores ambientais, tamanho de grão 


\section{Introduction}

Estuaries are among the most diverse and productive marine environments, they assimilate and process most of the river discharges and coastal basins, and have a unique position among coastal systems allowing a relatively simplistic view of water inflows and outflows (Pino et al., 1999; Tudurí et al., 2018; Grasso \& Le Hir, 2019). The degree of fluvial influence (as a result of precipitation in the drainage basin) affects not only sediment composition and distribution, but also controls salinity, nutrients, pollutants and biota distribution (Barroso et al., 2016; Costa et al., 2018).

The estuaries act as filters for the particulate and dissolved materials that originate in the drainage basin and are transported to the sea (Siegle et al., 2009), providing high levels of nutrients both in the water column and in the sediment (Grasso \& Le Hir, 2019). Determination and interpretation of sediment textural characteristics has a relevant role in studies of geomorphology and sedimentology (Pruthivraj et al., 2013; Balamurugan et al., 2014). These characteristics are primarily related to transportation and energy conditions of the environment (Pruthivraj et al., 2013), but also to the topography, wave and current pattern and depositional conditions (Karikalan et al., 2020). Grain size analysis is one of the relevant tools used in sedimentology to unravel hydrodynamics conditions, as can provide clues to the sediment attribution, transport history and depositional environment (Balamurugan et al., 2014).

Sediment dynamics (erosion, resuspension, deposition) are determined by the synergy betweenthehydrodynamic conditions(e.g. stream velocity) and sediment properties (e.g. grain size) at the water/sediment interface, which present a temporal variability in their measurements $(\mathrm{Ha}$ \& Park, 2012). The water depth also affects the hydrodynamics, mainly in microtidal estuaries, decreasing the hydrodynamic near the bottom surface with increasing depths, where smaller sediments may be found (Sedano et al., 2014).

Estuaries on microtidal coasts have several common characteristics as a result of low tidal currents in relation to wave action and the formation of small embayments (Cooper, 2002). In shallow estuaries, wind is an important factor that influences the resuspension of sediments, thus affecting the hydrodynamics, the biological and ecological processes of both the water column and the bottom (Ha \& Park, 2012).

Field measurements in some shallow estuarine zones (e.g. in the Deben estuaryEngland, Westerschelde estuary- Netherlands, Severn estuary-Great Britain) also show that the erodibility of cohesive sediments depends on its physical properties, such as sediment grain size and apparent density, and on biological variables, such as microphytobenthos and macroalgae sediment stabilization (Widdows et al., 2004; Fang et al., 2019). Thus, the seasonal cycle of erosion and deposition is reinforced by the biological cycles (van der Wal et al., 2010; Fang et al., 2019).

Sedimentological analyzes are useful tools to explain the complex mechanisms of estuaries (Kumar Maity \& Maiti, 2018). Sediments are typically described by particle size class distribution based on grain size logarithm (Avramidis et al., 2008). In addition to the mean size, the use of measures such as mean, variance and asymmetry highlight important features that may help in the interpretation of depositional environments and sediment transport (Avramidis et al., 2008; Kumar Maity \& Maiti, 2018). The distribution of sediment grain sizes is affected by several factors such as their source area, climate type, distance and energy of sediment transport in the depositional environments (Kumar Maity \& Maiti, 2018). Generally, fine sediments are well selected while coarse ones are poorly selected; negative asymmetries are associated with high energy environments and positive asymmetries with low energy environments (Friedman, 1961).

Sediments of muddy bottoms may vary in space and time as a consequence of bottom erodibility. This erodibility depends on interactions between physical processes, sediment properties and biological processes, particularly the balance between bio-stabilizers and bioturbators species (Widdows \& Brinsley, 2002; Huang et al., 2020). These variations in erodibility and sediment transport processes may play an important role in the seasonal variations of sedimentation and erosion (Andersen et al., 2005). In addition, 
water level fluctuations may also influence in the sediments grain sizes variations, being that when water level increases, there is an increment in fine sediments (Pruthivraj et al., 2013). In the Patos Lagoon, the winter and early spring seasons are characterized by strong winds inducing waves that cause erosion along the muddy bottoms (Möller et al., 2001). Even knowing the general spatial distribution of the bottom types of the main estuary, its channel (Antiqueira \& Calliari, 2005) and some embayments (Souza \& Hartman, 2008; Souza et al., 2008), the relationship between temporal variation and environmental parameters is still unknown.

Spatial distribution of sediment textural characteristics may suggest the direction of energy transport and its temporal variation reflects the fluctuation in energy regimes (Pruthivraj et al., 2013). Moreover, variations in organic matter dynamics represents a critical step to explain the carbon concentration/ composition, functioning and the energy flows along the estuarine food chain (Tudurí et al., 2018). This variability has been poorly studied in estuaries, even knowing that in other systems there is a complex dynamic in function of depth, the degree of exposure to environmental factors and the physical-chemical parameters that induce seasonal changes. Here we intend to show that in the Patos Lagoon estuarine system are different sub-environments depending on the textural characteristics (proportions of sand, silt and clay), the classification is not static as believed, and to contribute to the knowledge of these variations as the publications about the spatio-temporal variability on sediment texture are scarse.

In this sense, the aims of the present study were to evaluate the spatial and temporal changes in sediment texture in zones of different hydrodynamic conditions of the Patos Lagoon microtidal estuary and the influence of environmental parameters in these variations. To achieve this objective descriptive graph, univariate (correlations) and multivariate (Principal Components analyses and Permutational Multivariate analyses will be performed). Research works using multivariate statistical analyses have been widely published with numerous applications on marine and coastal geology (Pereira et al., 2010; Bitencourt \& Dillenburg, 2020 and references therein). The search for significant statistical findings in geomorphological studies, could give us a better understanding of which drivers play a major role in these changes, leading to better predictions (Bitencourt \& Dillenburg, 2020).

\section{Area, material and methods}

\section{1 Study area}

The Patos Lagoon is a chocked lagoon located at southern Brazil (Kjerfve, 1986), between Porto Alegre ( $\left.30^{\circ} 30^{\prime} \mathrm{S}, 51^{\circ} 13^{\prime} \mathrm{W}\right)$ and Rio Grande cities (32 ${ }^{\circ} 12^{\prime} \mathrm{S}, 52^{\circ} 5^{\prime} \mathrm{W}$ ), encompassing the space between the southern end of the Guaíba River and the mouth of the Patos Lagoon estuary which communicates with the southern Atlantic Ocean. The estuarine region had a single communication with sea through a channel of maximum depth of $18 \mathrm{~m}$. It is a microtidal estuary with mean tidal amplitude of $0.47 \mathrm{~m}$ (Fernandes et al., 2005) and, as most chocked lagoons of the world, the wind forcing effects are more important than tidal cycles, with little short-term variability (Kjerfve, 1986). The exposed margins of the estuary are dominated by fine sands and the shallow embayments by fine sediments (silt and clay), which also may be retained by saltmarshes.

The main inflow of freshwater at the north region comes from the hydrographic basin of the Guaíba system (the Jacuí, Taquarí, Caí, Sinos and Gravataí rivers), supplying $86 \%$ of its average total freshwater input. Water discharge of this drainage basin varies from 41 to $22,000 \mathrm{~m}^{3} \mathrm{~s}$ ${ }^{1}$ (Wallner-Kersanach et al., 2016). It has been estimated a suspended solid discharge from this system in up to 118,130 ton/day (Scotta, 2018). Sediments from these rivers drain regions are composed of Paleozoic sedimentary rocks and Mesozoic volcanic rocks from the Paraná Basin (Tomazelli et al., 2000). At central region the lagoon receives the inflow of the Camaquã river, which maximum inflow during flood periods can reach 5,000 $\mathrm{m}^{3} \mathrm{~s}^{-1}$ (Möller \& Castaing, 1999). This river drains the Crystalline Shield consisting of intrusive and metamorphic igneous rocks 
(Villwock et al., 1972). In the estuarine region, the lagoon receives inflow of the São Gonçalo channel which contribution came from the Mirim lagoon (Wallner-Kersanach et al., 2016). Sediments are mainly from Quaternary formations linked to the evolution or the coastal plain. This hydrographic basin contributes to the sedimentary dynamics inputting higher values of suspended sediments, calculated in $1.8 \times 10^{6}$ ton $_{\mathrm{yr}^{-1}}$ (Jung, 2017).

From all tributaries the Patos Lagoon receives $5.1 \times 10^{6}$ ton $\mathrm{yr}^{-1}$ of fine suspended sediments (Jung, 2017), but just the $25 \%$ reach the estuary (Baisch, 1998). The other $75 \%$ is deposited in the lagoon, where the coarse sediment is found in the shallow areas exposed to wave action, while silt and clay prevail in the deep channels and in the protected areas from wave action (Toldo et al., 2007). Precipitation plays a major role in these aspects, and as in most aquatic systems in South America is strongly affected by the El Niño Southern Oscillation (ENSO). During the warmphase ENSO events, the rainfall pattern increases in southeastern South America thus affects the hydrological system (Tudurí et al., 2018).

We analyzed the monthly precipitation values of all the drainage basin of the Patos Lagoon, through data obtained from the satellite MERRA-2 Model M2TMNXFLX v5.12.4 provided by the Giovanni online data system, developed by the NASA Goddard Earth Sciences Data and Information Services Center (NASA GES DISC). It was selected a square area limited by the coordinates $-54.8437,-32.2998,-50.0537$, -28.96 and downloaded the data of total surface precipitation from January/1997 to August/2017. Data showed that the sampled years that encompasses this work were characterized by extremely high precipitation rates, most of time over the mean values from the lasts 20 years. And as a consequence, the water levels of the estuary were higher too. The period fazed two El Niño events of different magnitude (2014-2015 weak and 2015-2016 very strong).

In addition to river discharge, the lagoon hydrodynamic is strongly influenced by the wind regime. Winds regulate the estuarine subtidal circulation in intervals of 3 to 16 days, coinciding with the passage of cold frontal systems (Fernandes et al., 2002). Northeast winds favor outflows of the lagoon water, generating sediment transport to the ocean. When the predominant winds come from the southwest, the Ekman transport piles up water close to the mouth, generating inflow currents which transport sediment inside the estuary (Möller et al., 2001). The estuarine region has a variable wave and current regime in function of the meteorological parameters and its morphometry, having in most of the area depth less than $1 \mathrm{~m}$, being the deeper zones associated to natural and human modified navigation channels (Souza \& Hartmann, 2008).

The study was carried out in the Arraial embayment, at the west margin of the Patos Lagoon estuary, which is partially protected for events of high energy and currents from the lagoon main channel (Fig. 1). This embayment is shallow (1-4 m depth), so the incidence of strong winds and low depth cause a highly dynamic environment with respect to the process of erosion, transport and deposition of sediments (Colling et al., 2007; Souza \& Hartmann, 2008).

\subsection{Sampling}

There were selected two areas: the protected area of the Pólvora island (island west side), and the exposed area of the Cavalos island (island east side), exposed to the influence of the main channel hydrodynamics and low frequency waves generated by the predominant NE wind (Fig. 1). In the first area we selected 4 sites (1P to 4P), and five in the second (1C to 5C) (Fig. 1). The depth was measured in each sampling, showing a variation between 0.9 - 4 $\mathrm{m}$, considering differences between sites and tidal variations. Even though there were subtle differences in depth within sampling sites, they were classified as shallow or deeper zones, as follows: the former those with mean depth less than $2.0 \mathrm{~m}(1 \mathrm{P}, 2 \mathrm{P}$ and $3 \mathrm{P}, 1 \mathrm{C}, 2 \mathrm{C}$ and $3 \mathrm{C})$, and the later those with mean depth equal or superior to $2.0 \mathrm{~m}$ which were near the navigation channel (4P, 4C and 5C) (Tab. 1). In addition, this classification is supported by the topobathymetric maps published by Alves et al., $(2018,2019)$ that shows a submerse bank extending from the Marinheiros Island that makes the bathymetry complex, mainly at the east margin of the Cavalos Island. 
In this sense, the apparently subtle differences in mean depth from site $3 \mathrm{C}$ with respect of sites $4 \mathrm{C}$ and $5 \mathrm{C}$, observing these maps, get support to separate site $3 \mathrm{C}$ as a shallow zone due to those sediment accumulations that makes the site remain in some periods as a very shallow area (1.5 $\mathrm{m}$ depth); that never occurs with sites $4 \mathrm{C}$ and $5 \mathrm{C}$ that are always with depths around or over $2 \mathrm{~m}$.

Samplings were performed between February 2015 and May 2017. The sampling strategy comprised between one and three times per season, with a total of 343 sedimentary samples. At each sampling point, two sediment samples were collected with a Van Veen grab and sub-sampled with a core of $10 \mathrm{~cm}$ diameter to separate a portion of $10 \mathrm{~cm}$ in diameter $\times 5 \mathrm{~cm}$ in depth. Samples were refrigerated until analyzed. Granulometric analyses were performed by dry mechanical sieving through a column of steelsieves of different mesh sizes from $4 \mathrm{~mm}$ to $0.063 \mathrm{~mm}$ and by pipetting analysis for grain sizes $<0.063 \mathrm{~mm}$, using approximately $30 \mathrm{~g}$ of sediment. The granulometric procedures followed the Wentworth classification system in intervals of one phi (Suguio, 1973). The grain size composition was expressed as the percentage of the total sample weight. Organic matter content was calculated by differences on weight before and after calcination for 2 hours at $375^{\circ} \mathrm{C}$, utilizing approximately $5 \mathrm{~g}$ of sediment.

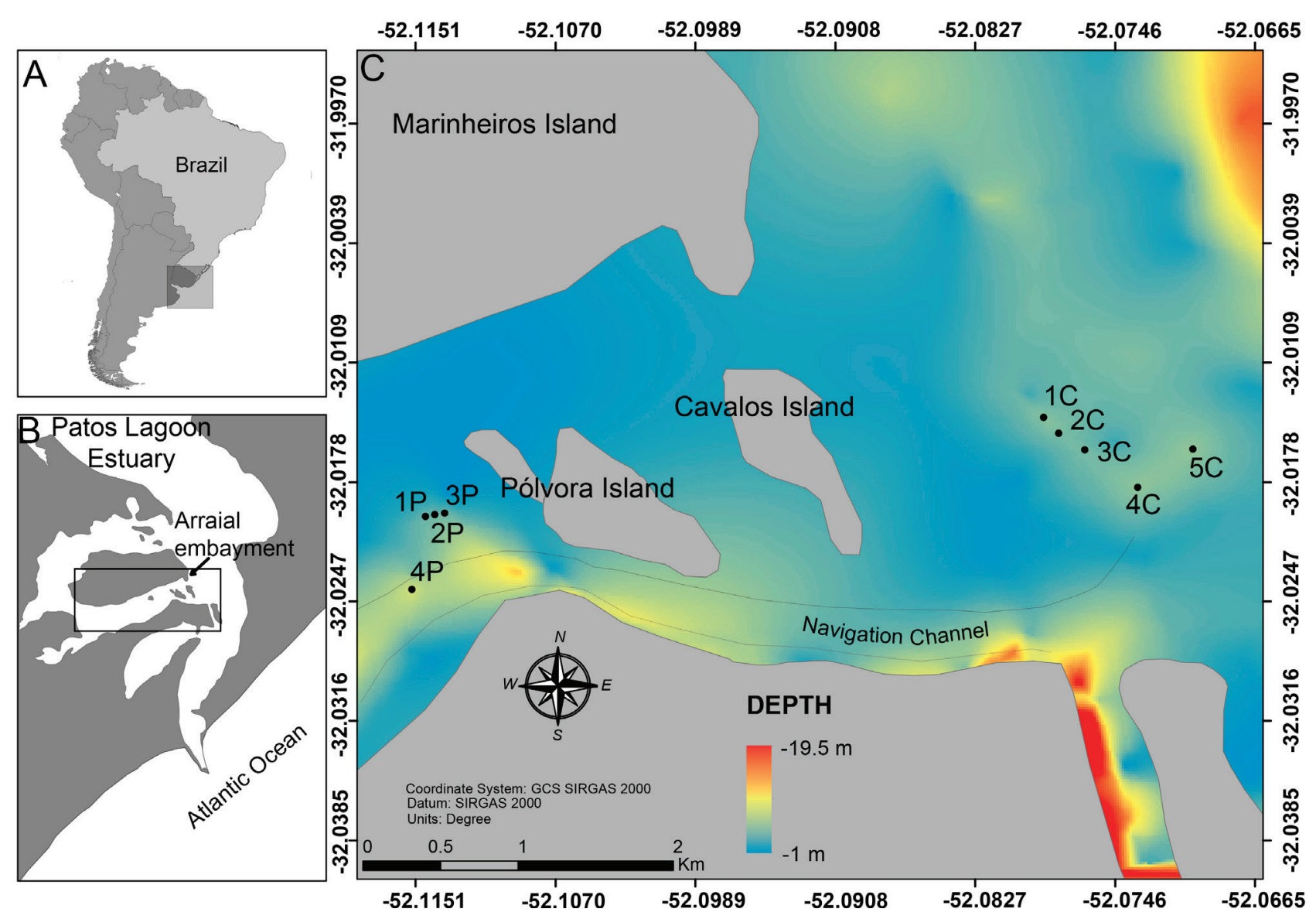

Figure 1. Bathymetric map of the study area with location of the sampling sites. A) Localization of the study area in relationship to the map of Brazil; B) Zoom of the Patos Lagoon estuary showing the Arraial embayment; C) Description of the sampling sites. Sites 1P-4P belong to the Pólvora island area and points 1C-5C belong to the Cavalos island area. Sites 1P-3P and 1C-3C were considered shallow zones and sites 4P, 4C and 5C deeper zones (Modified from Ortega et al., 2018).

Figura 1. Mapa batimétrico da área de estudo com a localização dos pontos de amostragem. A) Localização da área de estudo em relação ao mapa do Brasil; B) Ampliação do estuário da Lagoa dos Patos mostrando o Saco do Arraial; C) Descrição dos pontos de amostragem. Pontos $1 P-4 P$ pertencem à área da ilha da Pólvora e os pontos $1 C$-5C pertencem à área da ilha dos Cavalos. Pontos $1 P-3 P$ e $1 C$ - $3 C$ foram considerados zonas rasas e os pontos $4 P, 4 C$ e $5 C$ zonas mais profundas (Modificado de Ortega et al., 2018). 
Table 1. Classification and depths $(m)$ of each sampling site (minimum, mean and maximum dephts).

Tabela 1. Classificação e profundidades $(m)$ de cada sítio amostral (profundidades mínima, média e máxima).

\begin{tabular}{|c|c|c|c|c|c|}
\hline \multirow[t]{2}{*}{ Area } & \multirow[t]{2}{*}{ Zone } & \multirow[t]{2}{*}{ Site } & \multicolumn{3}{|c|}{ Depth (m) } \\
\hline & & & Min & Mean & Max \\
\hline \multirow{4}{*}{$\begin{array}{l}\text { Pólvora } \\
\text { island }\end{array}$} & Shallow & $1 \mathrm{P}$ & 0.9 & 1.3 & 2.0 \\
\hline & & $2 \mathrm{P}$ & 0.9 & 1.3 & 2.0 \\
\hline & & $3 \mathrm{P}$ & 0.9 & 1.3 & 2.0 \\
\hline & Deep & $4 \mathrm{P}$ & 1.5 & 2.7 & 4.0 \\
\hline \multirow{5}{*}{$\begin{array}{c}\text { Cavalos } \\
\text { island }\end{array}$} & Shallow & $1 \mathrm{C}$ & 1.5 & 1.7 & 2.5 \\
\hline & & $2 \mathrm{C}$ & 1.5 & 1.7 & 2.1 \\
\hline & & $3 \mathrm{C}$ & 1.5 & 1.9 & 2.1 \\
\hline & Deep & $4 \mathrm{C}$ & 1.9 & 2.1 & 2.6 \\
\hline & & $5 \mathrm{C}$ & 1.9 & 2.0 & 2.6 \\
\hline
\end{tabular}

Is important to highlight that in the whole study period dredging activities associated to channels and port basins which involves high remobilization of sediments to the water column with probable effects at superficial sedimentation were inexistent.

Water temperature was measured in situ with a mercury thermometer and salinity with a refractometer. Hourly data of wind speed and direction were obtained from the National Institute of Meteorology (Instituto Nacional de Meteorologia - IMET- Estação Rio Grande). It was calculated the wind mean speed and the wind direction mode for the 24 and $72 \mathrm{~h}$ previous to collect day. Möller et al. (2001) estimated that cold fronts which drives the conditions of wind speed and direction may last between 3 and 16 days.

Monthly mean of water level values for the period 1997-2017 was calculated from data of daily value recorded by the national agency of water (Agencia Nacional das Aguas - ANA station Rio Grande - Regatas). Waves closure depth was calculated with the methodology proposed by Hallermeier (1981): maximum water depth for nearshore erosion $(\mathrm{dl})=2 \mathrm{Hs}+11 \sigma$, and maximum water depth for motion initiation $(\mathrm{di})=$ $(\mathrm{Hs}-0.3 \sigma) * T s *(g / 5000 D)^{0.5}$. Where Hs= mean local significant wave height, $\sigma=$ standard deviation of significant height, Ts=mean significant wave period, $g=$ acceleration due gravity $\left(10 \mathrm{~m} / \mathrm{s}^{2}\right), \mathrm{D}=$ mean sediment diameter $(\mathrm{m})$. Waves data for the Patos Lagoon from January to July 2015 were provided by the program Rede Ondas of the Federal University of Rio Grande (http://www. redeondas.furg.br/index.php/pt/).

\subsection{Data Analysis}

The mean percentage of sand, silt and clay by season were plotted and classified by Shepard diagrams (Shepard, 1954). The statistical parameters were calculated following the equations of Folk \& Ward (1957), considering in the statistical analysis the mean, median, selection (standard deviation), asymmetry and kurtosis with the software SYSGRAN (Camargo, 1999). Spearman correlations were used to explore relationships between environmental parameters and sediment grain sizes.

To characterize the spatial and temporal variation of the areas based on the distribution of grain sizes and the statistical parameters, it was performed a Principal Component Analyses (PCA). A multivariate analysis of variance (Permanova) with residuals permutations under a reduced model, from a Euclidian distance matrix, was performed to evaluate the significance of the spatial and temporal variations of grain sizes and statistical parameters. The model design included the factors: Area (Pólvora island, Cavalos islandfixed), Site (the 9 sampled sites-random, nested in Area), Year (random) and Seasons (random, nested in Year). All analyses were performed with the software PRIMER V6 + PERMANOVA addon (Anderson et al., 2008) and R V3.4.1 (R Core Team, 2017).

\section{Results}

\subsection{Closure depth}

The maximum water depth for nearshore erosion by extreme wave condition (dl) was calculated based on the mean wave height (Hs $=0.37 \mathrm{~m}$ ) and its standard deviation $(\sigma=0.25$ $\mathrm{m})$, resulting in a depth of $3.48 \mathrm{~m}$. The maximum water depth for motion initiation by median wave condition (di) was calculated separately for the shallow zones of Pólvora island and Cavalos island (P1-P3, C1-C3), however both calculi gave the same result $(\mathrm{di}=8.82 \mathrm{~m})$. For the deeper zones of both areas (P4, C4-C5) we obtained the same result ( $\mathrm{di}=12.43 \mathrm{~m}$ ), which was nearly $50 \%$ deeper than for shallow zones. 


\subsection{Organic matter}

The organic matter content varied between 0 - 10.59\%, with higher values recorded in winter and spring of 2015. In addition, they were determined in the deeper sites of Cavalos island (4C and 5C) along 2015-2016. In some occasions (winter and spring of 2015, autumn and winter of 2016 and autumn of 2017) the deepest sampled site of Pólvora island (4P) had higher organic matter percentage than the other sites of the area (Fig. 2). The variability of organic matter percentage was fairly higher in spring than in the other seasons.

3.3 Relationship between grain size and environmental parameters

At the area of Pólvora island (exposed to S-SE winds) the wind direction in the $24 \mathrm{~h}$ prior to sampling was the most influent factor to/ the granulometric variation, correlated negatively with silt percentage and positively with medium and fine sands. This means that winds in the S-SE direction favored silt resuspension and thus increases the relative percentage of sand. In addition, wind speed also has a negative correlation with silt percentage, being that highspeed winds may also favor the resuspension of silt (Tab. 2). At the area of Cavalos island, wind was not correlated to sediment variability as was water depth. The water depth was positively correlated with silt and clay percentages and negatively with fine to very coarse sands (Tab. 2). Water temperature was negatively correlated with silt percentage in both areas, indicating that during cold months there was an increase in the relative percentage of silt.

\subsection{Spatial and temporal distribution of sediment texture}

Shallow zones of both areas (Pólvora island and Cavalos island) are composed mainly by sand, independently of seasonal or interannual variation (Fig. 3). At site 4P in winter of 2015 the

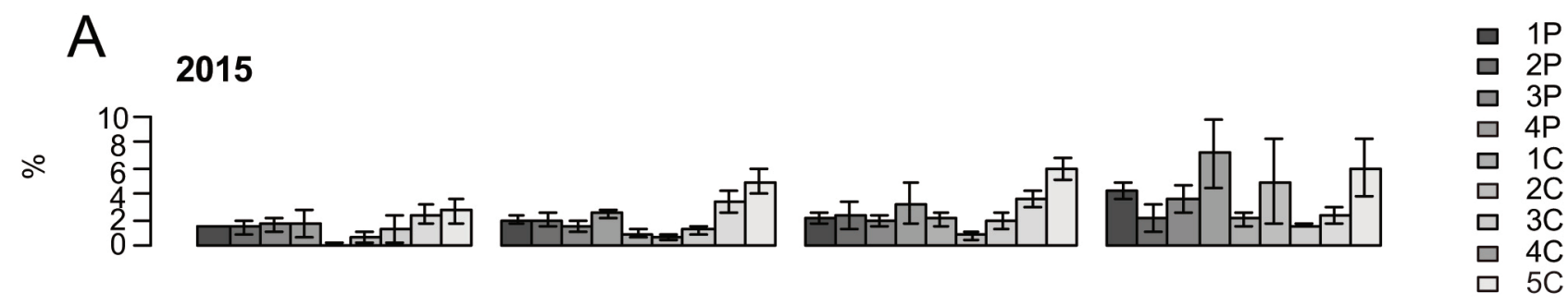

B

2016
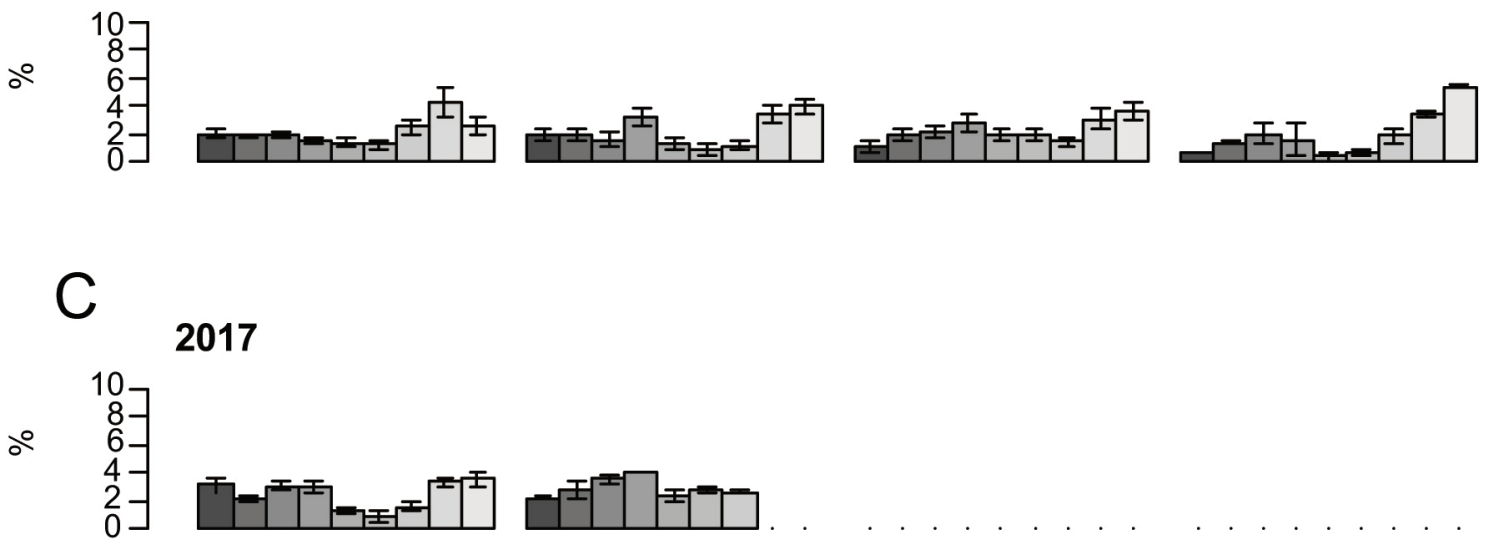

2017

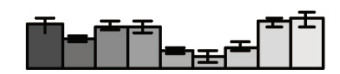

Summer

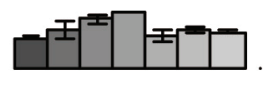

Autumn
Winter

Figure 2. Seasonal mean percentages of sediment organic matter at the nine sampled sites in years A) 2015, B) 2016, C) 2017. Vertical bars indicate standard error.

Figura 2. Porcentagens médias sazonais de matéria orgânica dos sedimentos nos nove pontos amostrados para os anos A)2015, B) 2016, C)2017. Barras verticais indicam o erro padrão. 
Table 2. Combination of parameters that resulted with significant Spearman correlations with sediment grain sizes $(\mathrm{p}<0.05)$.

Tabela 2. Combinação de parâmetros que resultaram com correlações de Spearman significativas com os tamanhos de grão do sedimento $(p<0.05)$.

\begin{tabular}{|c|c|c|c|}
\hline Area & Parameters & Rho & p-value \\
\hline \multirow[t]{10}{*}{ Pólvora } & Silt: Wind direction $24 \mathrm{~h}$ & -0.230 & 0.004 \\
\hline & Silt: Wind speed 24h & -0.196 & 0.015 \\
\hline & Silt: Salinity & 0.194 & 0.016 \\
\hline & Silt: Water Temperature & -0.238 & 0.003 \\
\hline & Fine sand: Wind direction $24 \mathrm{~h}$ & 0.213 & 0.008 \\
\hline & $\begin{array}{l}\text { Medium sand: Wind direction } 24 \mathrm{~h} \\
\text { Medium sand: Salinity }\end{array}$ & $\begin{array}{l}0.268 \\
0.238\end{array}$ & $\begin{array}{l}0.001 \\
0.003\end{array}$ \\
\hline & Medium sand: Depth & 0.362 & 0.004 \\
\hline & Very coarse sand: Depth & 0.344 & 0.013 \\
\hline & Mean: Wind direction $24 \mathrm{~h}$ & -0.256 & 0.001 \\
\hline & Median: Wind direction $24 \mathrm{~h}$ & -0.248 & 0.001 \\
\hline \multirow[t]{13}{*}{ Cavalos } & Silt: Water Temperature & -0.208 & 0.004 \\
\hline & Silt: Depth & 0.349 & 0.001 \\
\hline & Clay: Depth & 0.375 & $<0.001$ \\
\hline & Very fine sand: Depth & 0.436 & $<0.001$ \\
\hline & Fine sand: Depth & -0.398 & $<0.001$ \\
\hline & Medium sand: Depth & -0.333 & 0.003 \\
\hline & Coarse sand: Wind direction $24 \mathrm{~h}$ & 0.201 & 0.006 \\
\hline & Coarse sand: Depth & -0.162 & 0.026 \\
\hline & Very coarse sand: Wind direction $24 \mathrm{~h}$ & -0.145 & 0.046 \\
\hline & Very coarse sand: Wind speed $24 \mathrm{~h}$ & -0.150 & 0.040 \\
\hline & Very coarse sand: Water Temperature & -0.216 & 0.003 \\
\hline & Mean: Depth & 0.370 & $<0.001$ \\
\hline & Median: Depth & 0.370 & $<0.001$ \\
\hline
\end{tabular}

sediment can be classified as silty sand, changing in spring of this same year to clayey sand; on 2016 and 2017 it changed to sandy sediments. At site $4 \mathrm{C}$ the samples were classified as sand, but with a higher percentage of silt and clay than in shallower zones, and only in winter of 2015 were classified as silty sand. The site $5 \mathrm{C}$ was the most variable and with higher percentages of fine fractions. Over summer and autumn of 2015 sediments of this site were classified as silty sand, on winter changed to silty clayey sand and in spring changed again to silty sand but with a higher percentage of silt and clay than on summer and autumn. On summer and autumn of 2016 site 5C sediments were classified as sand and in winter and spring as silty sand, with higher percentage of silt and clay on spring. This classification remained until summer 2017 (Fig. 3).
The main grain sizes in both studied areas were those less than $0.250 \mathrm{~mm}$, thus we analyzed in details the seasonal variations of these sizes for each zone. For the area of Pólvora island there was a decrease of the very fine sediments (very fine sand, silt and clay) with the proximity to the island independently of the season. In this way, it was determined that sediments in Site 1P were composed by approximately $45 \%$ of these very fine sediments, the site $2 \mathrm{P}$ by $36 \%$ and $3 \mathrm{P}$ by $33 \%$. The site $4 \mathrm{P}$ (the deepest one) presented a seasonal variation, being summer the season with less very fine sediments ( 33\%), presenting a pronounced increase to $\sim 54 \%$ at spring (Fig. $4 \mathrm{~A})$.

Similarly, in the area of Cavalos island there was a decrease of very fine sediments with proximity to the island. The site $1 \mathrm{C}$ presented approximately $14 \%$ of very fine sediments, site 

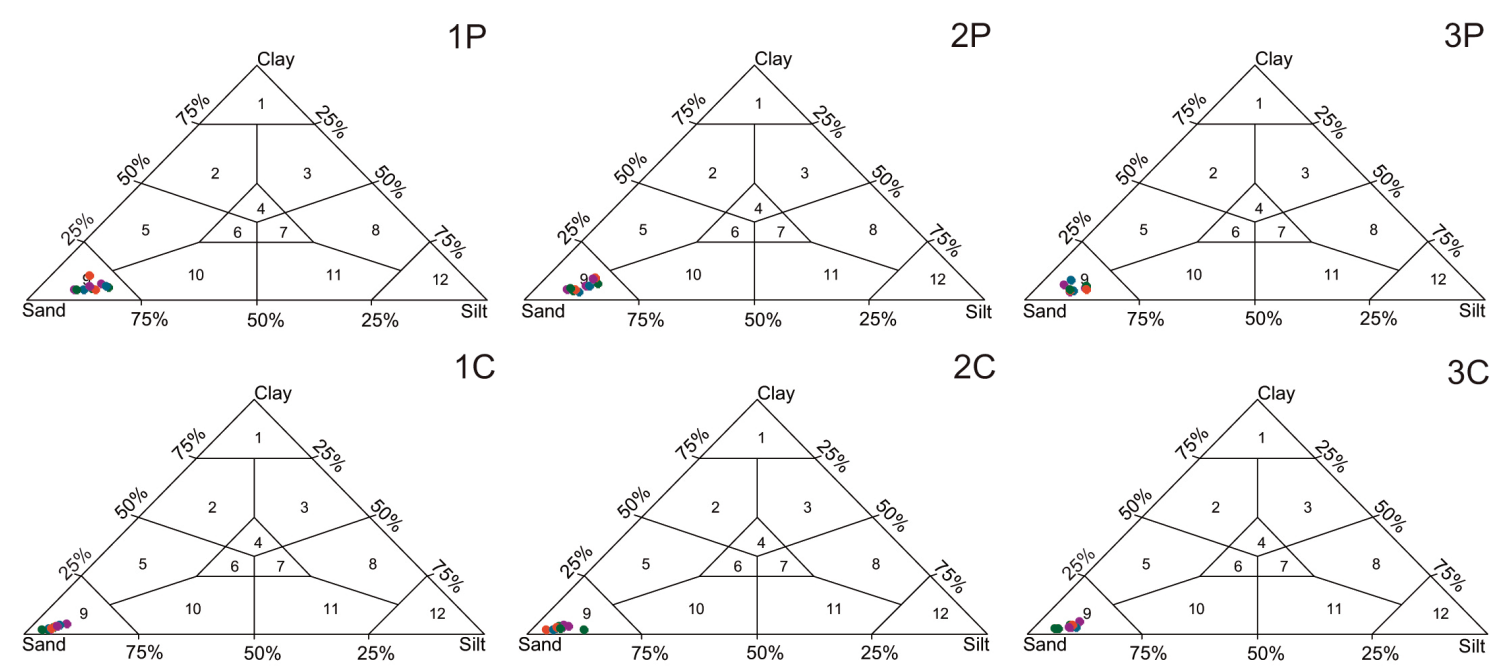

$4 \mathrm{P}$

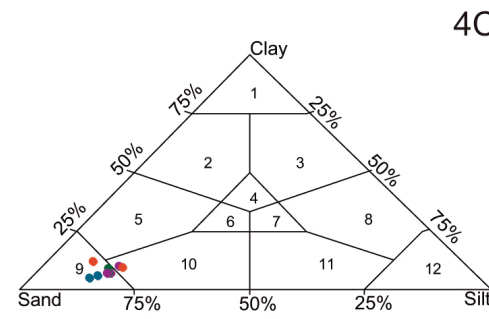

$4 \mathrm{C}$
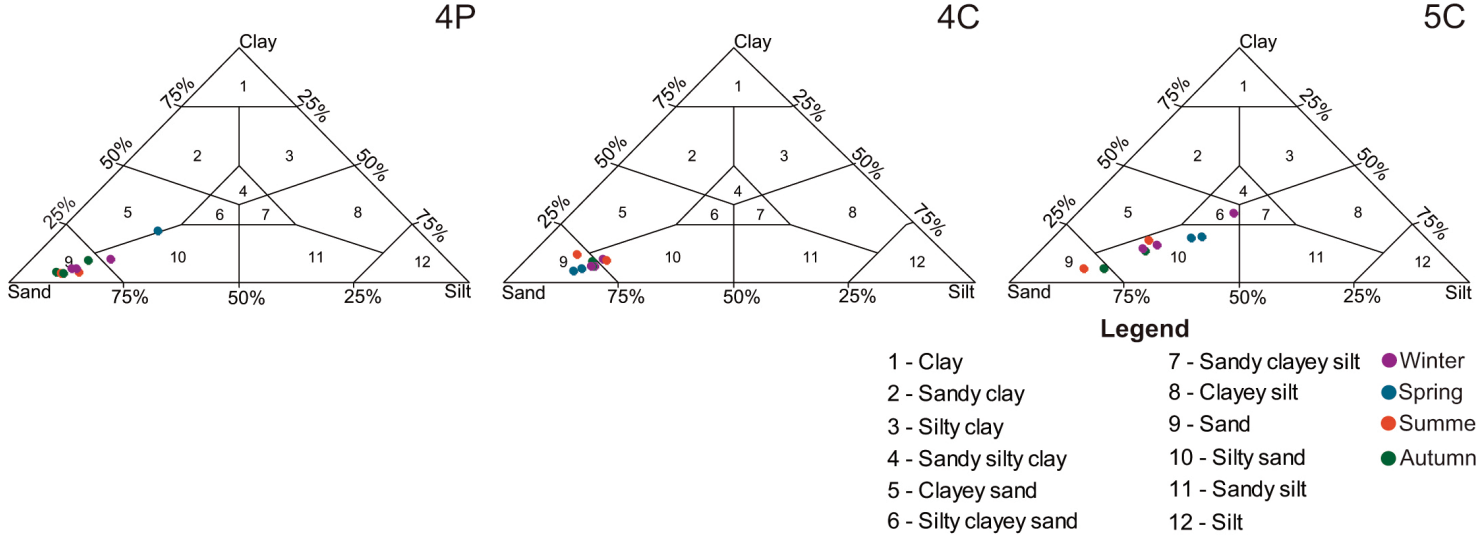

$$
\begin{array}{ll}
7 \text { - Sandy clayey silt } & \text {-Winter } \\
8 \text { - Clayey silt } & \text {-Spring } \\
9 \text { - Sand } & \text {-Summer } \\
10 \text { - Silty sand } & \text { - Autumn } \\
11 \text { - Sandy silt } & \\
12 \text { - Silt } &
\end{array}
$$

Figure 3. Shepard ternary diagram with seasonal mean values of sampled sediments over the three studied years on the Patos Lagoon estuary. Sites 1P-3P correspond to shallow zones of Pólvora island, 1C-3C shallow zones of Cavalos island, 4P deeper zone of Pólvora island and 4C-5C deeper zones of Cavalos island.

Figura 3. Diagrama ternário de Shepard com valores médios sazonais dos sedimentos amostrados nos três anos estudados no estuário da Lagoa dos Patos. Os pontos $1 \mathrm{P}-3 \mathrm{P}$ correspondem a zonas rasas da ilha da Pólvora, 1C-3C a zonas rasas da ilha dos Cavalos, 4P zona mais profunda da ilha da Pólvora e 4C-5C zonas mais profundas da ilha dos Cavalos.

2C presented $16 \%$, site $3 \mathrm{C}$ a $22 \%$, site $4 \mathrm{C}$ a $55 \%$ and $5 \mathrm{C}$ a $71 \%$. In the site $5 \mathrm{C}$ was observed a high seasonal variation with a gradual increase of the fine sediments from summer to spring, arising to $83 \%$ of the granulometric composition (Fig. 4B).

Comparing both areas, it was observed that the shallow zones presented a higher stability of granulometric composition, being finer in the Pólvora island. In contrast, deeper zones presented a broad seasonal variation, being the very fine sediments the most representatives in both areas (Fig. 4).

The principal component analysis (PCA) explained the $70.4 \%$ of variation between zones, based on the grain size (Fig. 5A). The analysis showed a clear separation between the four studied zones (shallow and deeper zones of Pólvora and Cavalos island, respectively). Samples of each site remained inside its group independently of seasonal variations in almost all cases. Depth was an important factor separating groups in both axes, so as the grain size.

The first axis clearly separates the shallow and deeper zones from the Cavalos island area, showing that shallow zones presented a higher content of medium and fine sand, while the deeper zones presented higher values of very fine sediments. The second axis separates the shallow and deeper zones of the Pólvora island area, where the deeper zones presented high percentages of very coarse and coarse sediments, which were not present in the shallow zones (Fig. $5 \mathrm{~A})$. This imply that different processes were acting in the Pólvora and Cavalos islands areas, so different drivers, probably due to exposure degree, explain the separation between shallow and deeper zones of each area. 


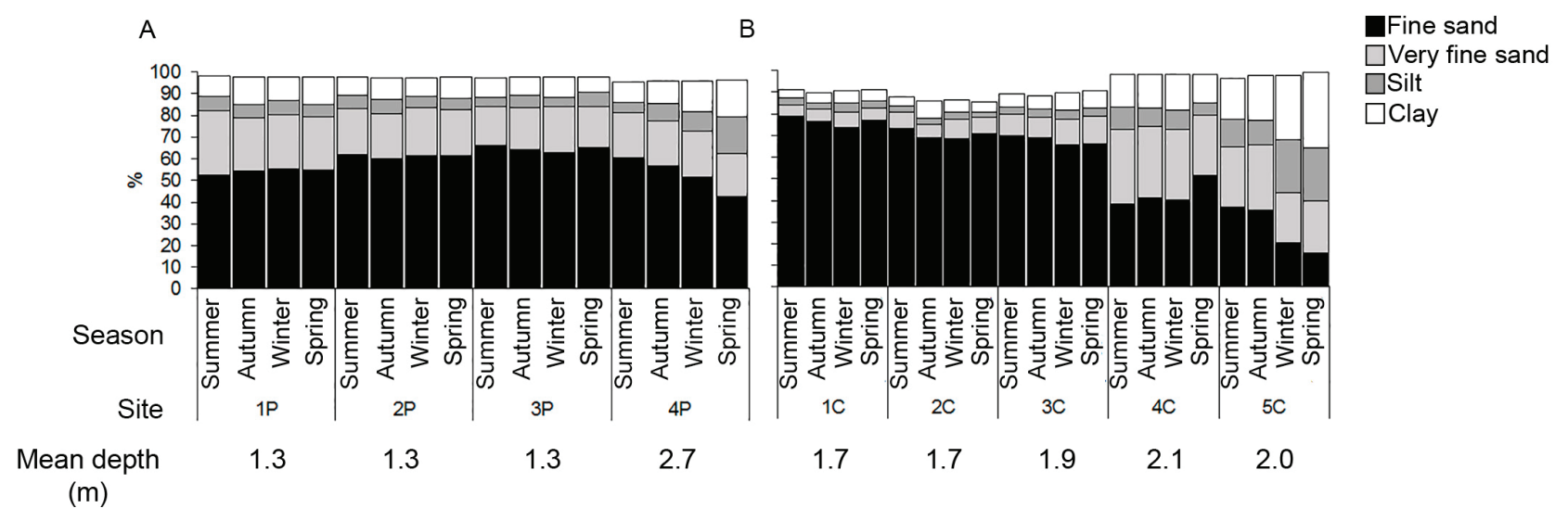

Figure 4. Seasonal variation of the main granulometric fractions of each site. A) Pólvora island area, B) Cavalos island area.

Figura 4. Variação sazonal das principais frações granulométricas de cada ponto amostral. A) Área da ilha da Pólvora, B) Área da ilha dos Cavalos.

No-significant differences were found between the areas of Pólvora island and Cavalos island, however, sites within them were different (Pseudo-F=54.58, $P=0.001$ ). Temporarily, there were significant differences between years (Pseudo- $F=2.54, P=0.021$ ) and a different seasonal variation in sites within each area (Pseudo-F=1.62, $P=0.005$ ). Pairwise tests showed that differences between sites on the Pólvora island were mainly due to the distance from the island and disappear on spring. In the Cavalos island almost all period presented significant differences between all sites.

The principal component analysis based on grain size statistical parameters (Fig. 5B) explained the $87 \%$ of variation between zones, being the mean grain size the coefficient with higher value. Basically, the first axis explained most of the variability (59.6\%) and second axis explained $27.4 \%$. The graph clearly separates the shallow zones of the Cavalos island area from the deeper zones of this area, mainly due to the standard deviation (Fig. 5B).

There were significant differences in the median and skewness parameter among seasons per site (median: Pseudo-F $=2.6618$, $\mathrm{P}=0.001$, skewness: $\quad$ Pseudo- $\mathrm{F}=2.3924$, $\mathrm{P}=0.006)$. At Pólvora island area, the deeper point (4P) presented lower median values in summer than spring (Fig. 6A). At the Cavalos island, sites $1 \mathrm{C}$ and the deeper ones ( $4 \mathrm{C}$ and $5 \mathrm{C}$ ) showed significant differences on winter and spring, with lower values in the second one (Fig. 6A). Skewness presented significant differences only in the deeper sites of both areas (Fig. 6C). Other parameters did not show significant differences. An important thing to note is that deeper zones from both areas are near de navigation channel, this may be a relevant factor influencing the greater dispersion of data in these zones.

The relationship between grain size statistical parameters through scatter plots allowed the identification of sedimentary subenvironments in relation to its energy level. In this sense, Figure 7 shows the relationship between mean and skewness evidencing four different populations. The shallow zones near Cavalos island with larger grain sizes (lower mean value in the phi scale) and a skewness between 0.3-0.4. The zones near Pólvora island showed a higher value of skewness, which tilts data to the fine fractions, corresponding also to a smaller mean size. The site 4C showed a skewness even higher, implying in a higher tendency to the fine fractions, with a mean size even smaller. Site $5 \mathrm{C}$ and the spring values of site $4 \mathrm{P}$ as the fourth group with the lowest mean values and a skewness towards the fine fractions (Fig. 7). 

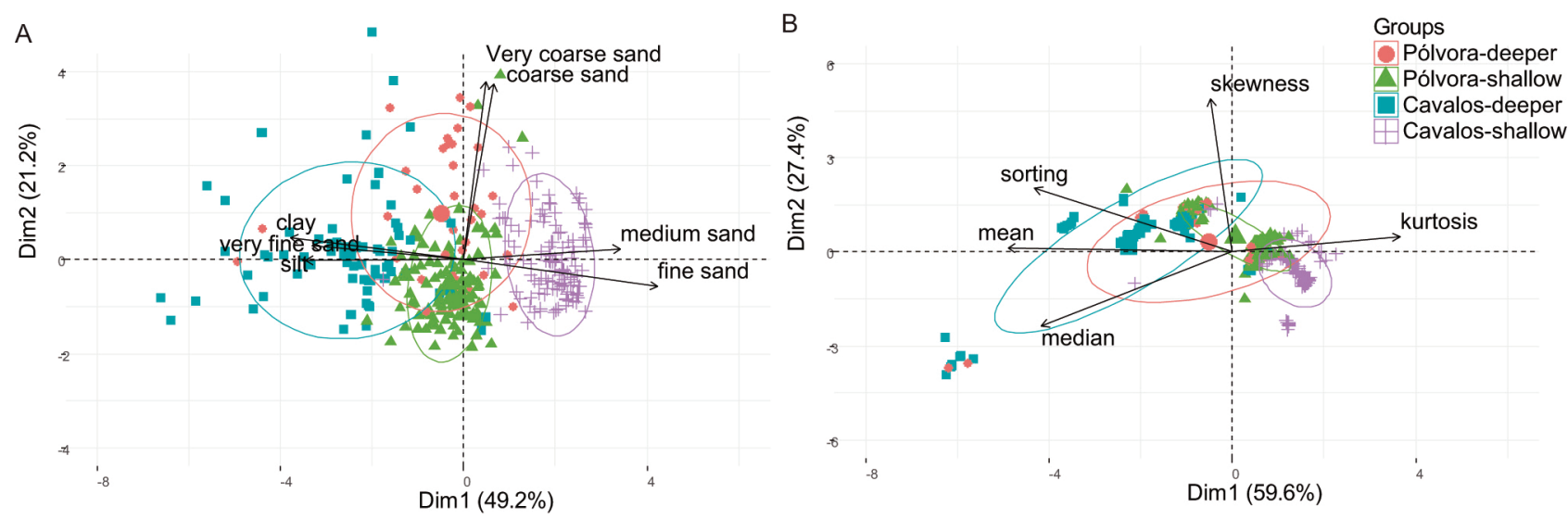

Figure 5. Principal component analysis showing the spatial and temporal variation in sediments between sampled zones. A) based on grain size distribution, B) based on grain size statistical parameters. Ellipses grouped $70 \%$ of points from each centroid.

Figura 5. Análise de componentes principais mostrando a variação espacial e temporal dos sedimentos entre as zonas amostradas. A) com base na distribuição de tamanho de grão, B) com base em parâmetros estatísticos de tamanho de grão. As elipses agrupam $70 \%$ dos pontos de cada centroide.

\section{Discussion}

Sediments deposited into estuaries are influenced by a variety of processes like river discharge, tidal height, wind speed, the concentration of suspended sediments and flocculation, as demonstrated in the Severn estuary-Great Britain (Allen \& Duffy, 1998; Manning et al., 2010), Scheldt estuary-Netherland (Temmerman et al., 2003) and Pearl River DeltaChina (Huang et al., 2020). Shallow embayments are less understood than saltmarshes and sandy beaches because of the cohesive nature of its sediments, which are often very soft (Dyer et al., 2000). It is vital the understanding of sediment transport for prediction of the evolution of bathymetry, water quality, and ecology in estuaries and coasts (Huang et al., 2020).

The soft bottoms in these embayments are variable in function to the morphodynamic processes involving water circulation and bottom morphometry (Vieira et al., 2020), for example, exposure level, depth and the relative localization according to wind and waves forcing effects. Particularly, strong currents and the action of wind induced waves affects shallow subtidal flats (Vieira et al., 2020). This causes sediment remobilization and difficult the deposition of fine material, favoring the predominance of coarser grain sizes (Dyer et al., 2000; Santos et al., 2004;
Souza \& Hartmann, 2008). The stress caused by wind induced waves is a function of waves height and water depth. The wave height depends on wind speed and direction, storm duration and water depth in the wave generation area (Viitak et al., 2016).

Wind is the main factor driving the circulation patterns of the Patos Lagoon in periods of low river discharge (Möller et al. 2001; Martelo et al., 2019). The NE winds, predominant along year, form a pressure gradient that favors the seaward flows, while SW winds predominant in winter and spring favors the landward flows (Möller et al., 2001; Fernandes et al., 2002). Simultaneously, there exist a seasonal pattern of the fresh water discharge with higher flows in winter and spring and low flows at summer and autumn (Möller et al., 1996). This may explain the higher abundance of organic matter percentages on winter and spring, as the drainage basin provide large amounts of suspended sediments that will deposit in the less hydrodynamic zones of the estuary. In addition, high peaks of current velocity in winter and early spring reflect the low salinity intrusion in the estuary, being the seasonal variability of estuarine discharge related with the variability of river discharge inside the Lagoon (Martelo et al., 2019). Coinciding with this, Pino et al. (1999) reported high seasonality in the organic matter percentages and muddy 

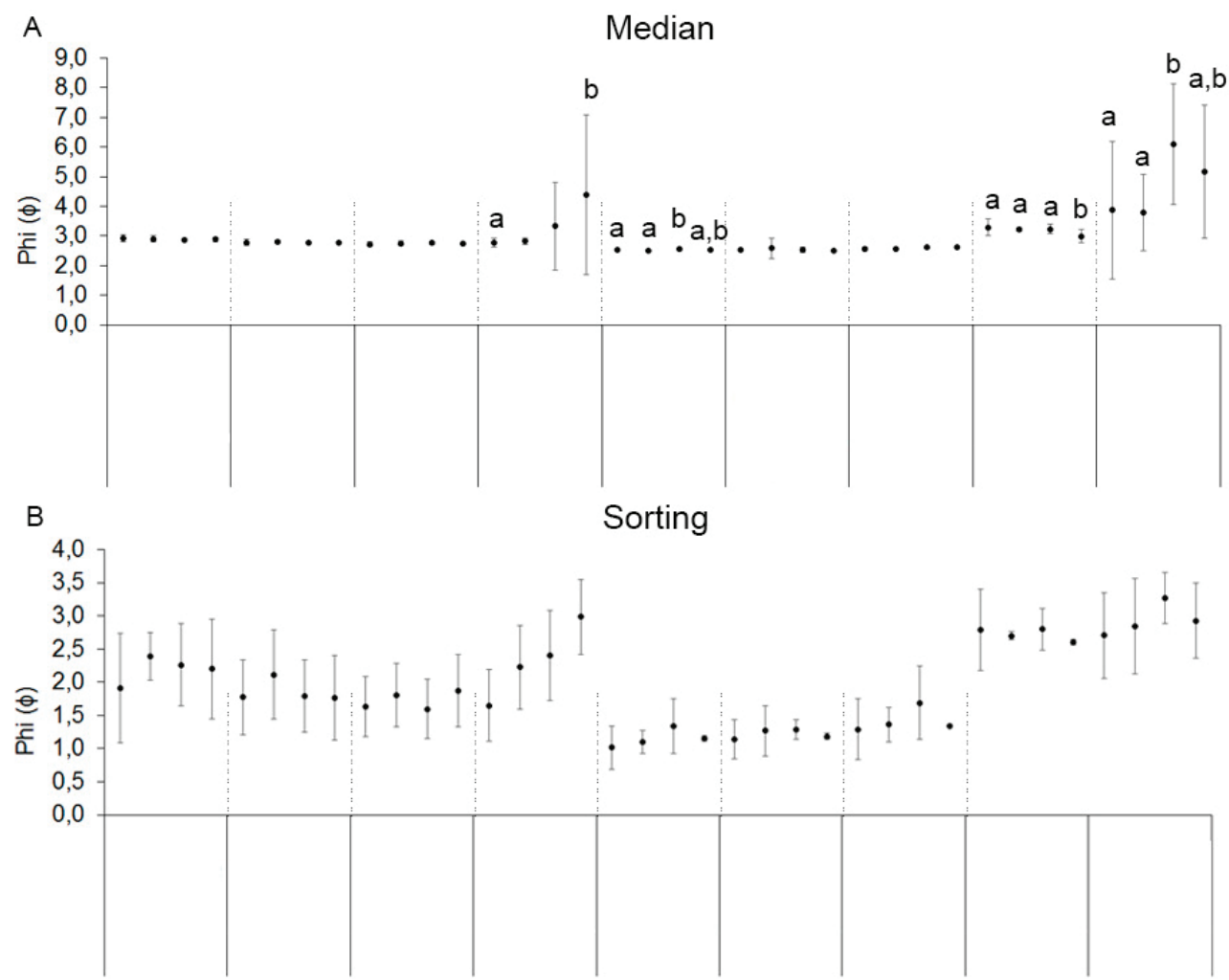

C

Skewness
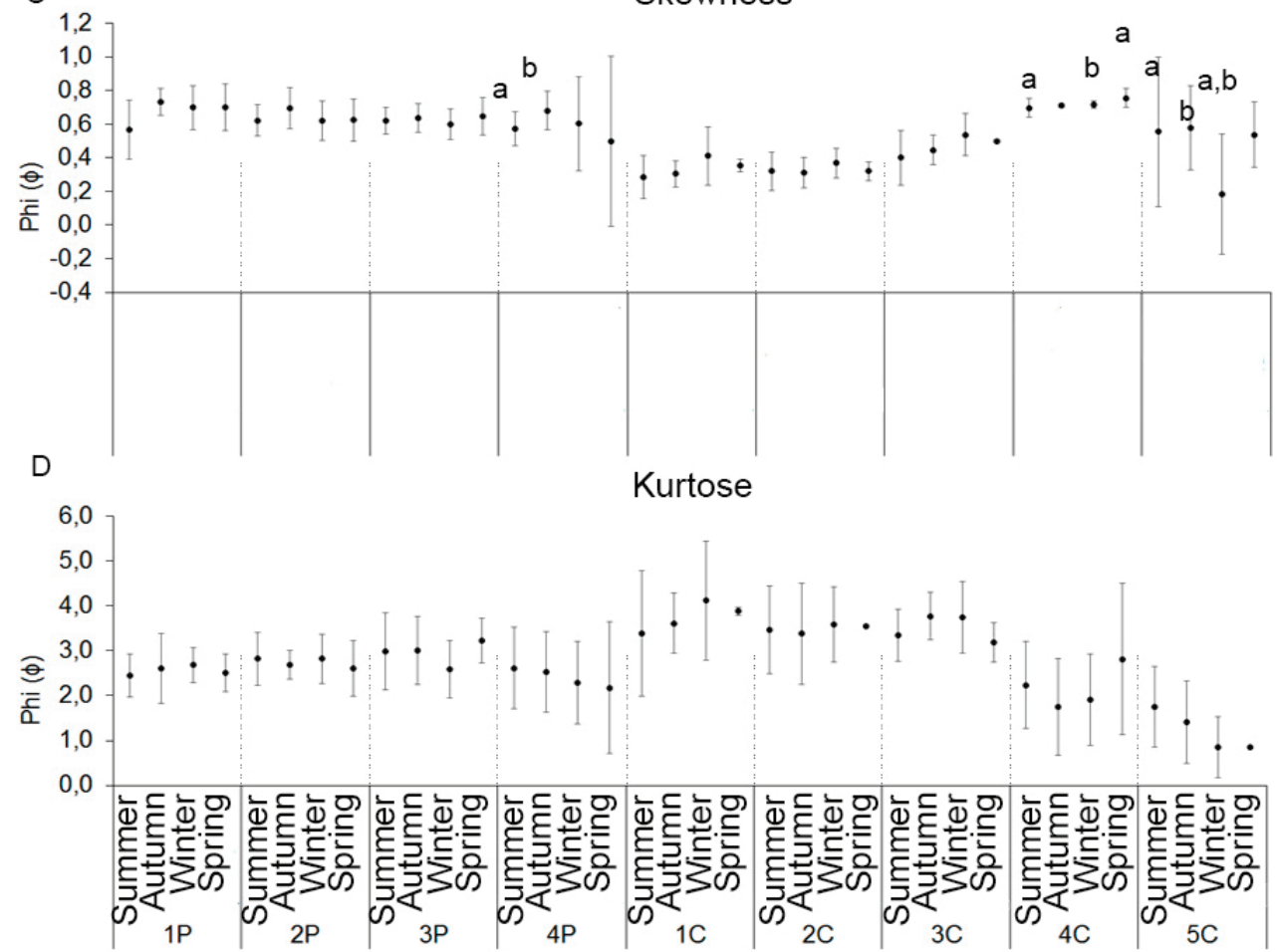

Figure 6. Seasonal variation of grain size statistical parameters for each site. A) Median, B) Standard deviation C) Skewness, D) Kurtose. Vertical bars indicate the standard error. Low-case letters indicate significant variations among seasons for each site $(\mathrm{P}<0.05)$.

Figura 6. Variação sazonal dos parâmetros estatísticos de tamanho de grão para cada ponto amostral. A) Mediana, B) Desvio padrão, C) Assimetria, D) Curtoses. Barras verticais indicam o erro padrão. Letras minúsculas indicam variações significativas entre as estações para cada ponto $(P<0,05)$. 


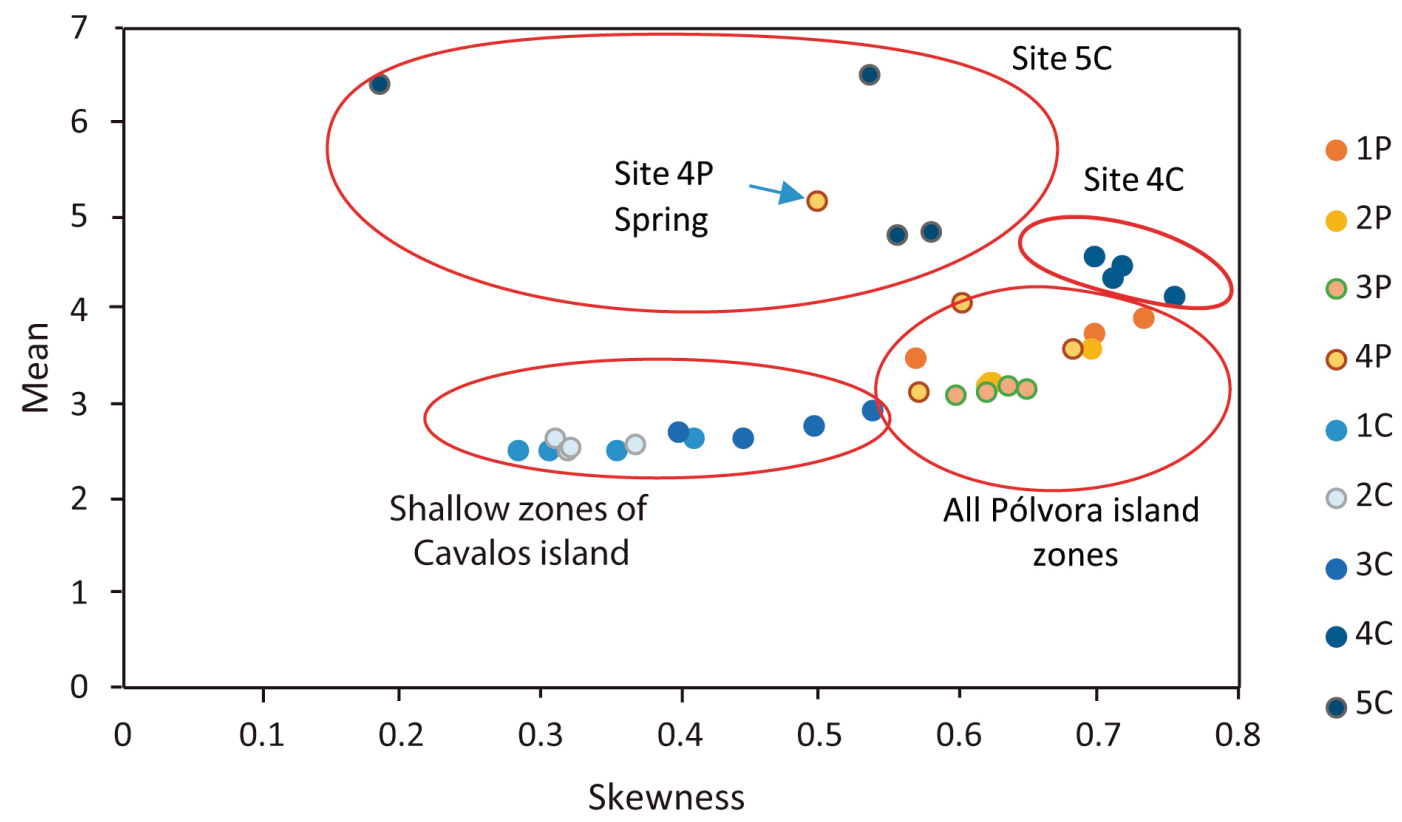

Figure 7. Scatter plot between mean grain size and asymmetry. Figura 7. Gráfico de dispersão entre a média e assimetria do tamanho do grão.

sediments with peaks in winter for the Queule estuary (Chile). Also, in the Arasalar estuary (India) (Bragadeeswaran et al., 2007) and Kemaman estuary (Malasya) (Kamaruzzaman et al., 2002) higher clay content was recorded during the post monsoon (rainy period). Even when water temperature showed high correlation values with the very fine sediments, we believe in an indirect correlation which coincide with seasonality of winds and river discharge.

The geographic trends in sediment particle size distribution correspond with bathymetric variations, where generally there is an increase in fine sediments toward deeper zones (Pruthivraj et al., 2013; Balamurugan et al., 2014). Particularly in the Patos Lagoon, the sedimentation pattern is composed of coarse fractions at the margins and regions with intense hydrodynamics and fine sediments settle at the deeper parts of the lagoon (Martelo et al., 2019). According to this, the deeper zones of studied area have a higher percentage of organic matter probably due to the lower influence of winds and waves causing resuspension of sediments, and also were the zones that presented the highest seasonal variation in grain size. These findings are probably a result of wind induced waves generated over the lagoon that may erode until $3.48 \mathrm{~m}$ depth. This limit is close to the maximum depth sampled, indicating that bottom remobilization in deeper zones may occur by wind action, even with less force than in the shallow zones. We highlight that the large depth differences recorded in the site 4P may be due to the fact that the sample point was very close to the navigation channel. Therefore, sampling near the navigation channel edge in some campaigns, the dredge could have fallen further down the edge of the channel. In this sense those larger differences do not imply that there were high tidal effects, as the studied estuary is a microtidal one. In shallower zones, the short period and low amplitude of the wind induced waves are able to cause greater resuspension and to hinder the deposition of the finer sediments.

Hirata et al. (2010) observed that the long-term water level oscillations in the Mirim lagoon (connected to the Patos Lagoon estuary) were strongly linked to the El Nino-Southern Oscillation (ENSO). Considering the Patos Lagoon estuary water level from 2014 to 2016 there were long periods of high precipitation 
rates in all the drainage basin, including two El Niño events (one weak and one very strong). These events in the Patos Lagoon increase the freshwater discharges, decreasing salinity and increasing the fine sediment loads into the estuary (Fernandes et al. 2002; Barros et al. 2014; Vieira et al., 2020). This abnormal long period of high lagoon water level may also be favored by the elongation of the jetties in the Barra of Rio Grande in 2011, as modeled by Fernandes et al. (2005) analyzing possible scenarios of changes in the circulation of the estuary as a consequence of the jetties elongation. The model showed that this magnification could lead to an increase in seaward flow and a decrease in landward flows, a decrease in the distance reached by salt water and an increase in the water level inside the estuary.

These scenarios may explain the higher percentage of organic matter when compared with previous studies in nearby areas like the Pombas island mudflats (Patos Lagoon estuary). There were observed organic matter percentages between 0.2 - 0.8\% (Rosa \& Bemvenuti, 2004) and 0.09 - 3.15\% (Rosa \& Bemvenuti, 2006) during years without the influence of El Niño; and $0.74-1.22 \%$ (Colling et al., 2010) during years with influence of the El Niño event (2002-2003). Also, in the Pombas island there was observed a different pattern for the organic matter content. Instead of an increase of fine sediments and organic matter percentages simultaneously with the increases of water discharge, the organic matter increments were recorded only during months after higher freshwater discharge and was related to the benthic recovery of post-El Niño (Colling et al, 2010), similar with observed in this study. Our results were similar to the patterns observed in the Pearl River Estuary were in wet seasons there is an increment in organic matter percentages due to dominance of terrestrial and freshwater algae (Ye et al., 2017).

The wind induced waves from NW-SW and NE-SE directions, which may reach $0.2 \mathrm{~m}$ height and a frequency of $5 \mathrm{~s}$ reach the island's shore causing erosion (Marangoni \& Costa, 2009). In this sense, when NE-SE winds are strong, they resuspend sediments at the exposed side of Cavalos island and nearby areas, causing erosive events implying sediment transport. These sediments will deposit in the most protected areas and with less hydrodynamics, as are for example the zones of greater depth in the channels and the areas to the west side of the Arraial embayment islands (Souza \& Hartman, 2008). In the Yangtze delta, there was observed that wind (by changes in hydrodynamic and inducing waves) may induce daily to seasonal changes in surface sediment grain size on unvegetated flats which contributes to process of accretion and erosion (Yang et al., 2008).

Sediment texture in both studied areas of the Arraial embayment indicates a predominance of sandy facies, in spite of the differences between the sites, mainly regarding the content of silt and clay. This coincide with previous reports of Antiqueira \& Calliari (2005) and Tomazelli \& Villwock (2000), who found that in the shallower areas below the $4 \mathrm{~m}$ depth of the Patos Lagoon the sediment is predominantly sandy. Souza et al. (2008) surveyed the texture of bottom sediments for the same estuarine area, observing that the region adjacent to the western margin of the Pólvora island was composed of silty sand, but with sandy regions to the north of the island. In our results these same sites located on the western margin of the Pólvora island were composed mainly of sand during the four seasons of the year, indicating a greater resuspension of fine sediments when compared to previous data. The shallow sites in the exposed part of the Cavalos island, composed mainly by sand bottoms, coincide with that observed by Souza et al. (2008). Although both areas are predominantly sandy, it was observed that the exposed areas on the eastern side of the Cavalos island presented larger amounts of coarse fractions while the protected areas on the western margin of the Pólvora island had larger amounts of fine sediments. It should be noted that the coarsest sediment fractions found were calcareous detritus of bivalves and gastropods shells, which are abundant in these soft bottoms. However, as seen in the Figure 4, the percentage of granulometric composition they represent was very low.

The higher percentage of medium to coarse sand at points close to Cavalos island reflects the 
hydrodynamics generated by local circulation on the area, where the sites located at the east side of the island are more exposed to the greater energy of the water associated with the main channel of the lagoon. Souza \& Hartmann (2008) recorded that the distribution of the sediments in this area is interspersed with abrupt contacts between fine sand and medium silt and also with the occurrence of biodetritus of the mollusk Erodona mactroides.

Within the shallow zone of Pólvora island the bathymetry is more similar and shallower than within the zones of Cavalos island. This opens a gap for the wind to have a greater influence on resuspension, erosion and sediment transport, being therefore one of the factors with higher correlation in granulometry variations. While in the sites of Cavalos island there are more variations on bathymetry, reflecting in less direct influence of wind in the variations of granulometry and a higher correlation with depth. The deeper zones of both areas (Sites 4P, 4C and 5C) were nearby the navigation channels. It has been recognized that these channels are deposition areas (Souza et al., 2008), which explains higher percentages of fine sediments. Antiqueira \& Calliari (2005) also reported that exist a direct correlation between depth and fine sediments, coinciding with observations in the present study. In both areas it was observed a decrease of fine fractions according to the proximity of the islands. Similarly, in the Pearl River estuary (China), sediments are finer in the channel areas than in the shoal areas, and they expose that this difference explain why the channel areas are more subject to erosion, as sand fraction have a negative effect on the erodibility of seabed (Huang et al., 2020).

In addition to the direct effect of environmental agents, the influence of benthic organisms on the erosion of fine sediments must be considered (Fang et al., 2019; Hillman et al., 2020). Organisms comprising the microphytobenthos like diatoms, and macrofaunal species like polychaetes secrete mucus that can perform a resistance force against erosion processes, by increasing the cohesion among grains (Fang et al., 2019; Hillman et al., 2020). Bivalves, amphipods and decapod crustaceans, in contrast, tend to destabilize the sediment in the construction of its galleries (Kornman \& De Deckere, 1998; Dyer et al., 2000). Other bivalves may act as stabilizer or destabilizer depending on the habitat (Hillman et al., 2020). In this sense, the establishment of benthic communities may have an important influence on the erosion and sediment transport processes (Widdows et al., 2000; Widdows \& Brinsley, 2002; Fang et al., 2019; Hillman et al., 2020). Declining biological productivity along with strong winter storms facilitates erosion, creating a cycle of erosion and deposition (Dyer et al., 2000). It has been reported that on shallow areas of the Patos Lagoon estuary occurs a decrease of macrofauna during winter periods (Bemvenuti \& Netto, 1998; Rosa \& Bemvenuti, 2006; Ortega et al., 2018), which can be extended to spring at high precipitation periods with consequent decrease on salinities (Colling et al., 2007, Ortega et al., 2018). The years 2015-2017 were years of high rainfall mainly in the spring, causing decline of the macrofauna (Ortega et al., 2018), which could facilitate together with the strong winds the erosion of the sediment of the shallow sites and their deposition in deeper zones.

This is the first study that analyzed the spatial and temporal patterns of sediment grain sizes in shallow areas of the Patos Lagoon estuary and relate them to environmental variables. The understanding of this variability is important to consider when analyzing benthic faunal changes, anthropogenic impacts on estuarine bottoms and to better understand the sedimentation processes in an estuary.

\section{Conclusions}

We concluded that centimeters of difference in depth and degree of exposure to environmental factors may cause large variability in the sedimentology of shallow estuarine areas. The shallower areas have higher content of very fine sand, due to the remobilization of fine sediments by the action of low amplitude and period waves. The estuarine internal channels have lower bottom dynamics since waves usually cannot remobilize fine sediments. In this sense, the higher variability of zones $4 \mathrm{P}, 4 \mathrm{C}$ and $5 \mathrm{C}$ is due to their subtle differences in depth and the 
consequently lower fine sediments remobilization action from wind induced waves. The estuarine internal channels have low current action and waves are more effective in remobilizing fine sediments. Thus, the apparently small differences in one parameter can produce changes in the whole sediments characteristics leading to temporal variation in sediment texture and organic matter content in the shallow areas of the Patos Lagoon estuary. The temporal changes are due to: deposition of fine sediments and organic material from terrestrial and freshwater origin, being rainfall rates the main driver in seasonality; to the benthic organisms influence, controlled by seasonal variations in temperature and salinity; and the seasonality of wind induced waves. The results of the main forcing abiotic factors imply a greater variation in the sedimentary bottom texture towards greater depths, following atmospheric and hydrographic trends.

Acknowledgements. To all personnel involved in the field trips and laboratory works. To Gloria Paz Canteiro (In Memoriam) for her invaluable help in the granulometric analyses. To Valerio Costa Machado for map elaboration. To the Coordenação de Aperfeiçoamento de Pessoal de Nivel Superior (CAPES) for the grant to lleana Ortega. This work was supported by the projects REBYC LAC - II FAO (FAO- GCP/RLA/201/GFF and GEF Project ID 5304) and the Brazilian Long-Term Ecological Research (PELD) (Conselho Nacional de Desenvolvimento Científico e TecnológicoCNPq, \# 403805/2012-0). Precipitation data was produced with the Giovanni online data system, developed and maintained by the NASA GES DISC

\section{References}

Allen, J.R.L. \& Duffy, M.J. 1998. Temporal and spatial depositional patterns in the Severn Estuary, southwestern Britain: intertidal studies at spring-neap and seasonal scales, 1991-1993. Marine Geology, 146: 147-171.

Alves, D.C.L., Espinoza, J.M.A., Albuquerque, M.G., Silva, M.B, Fontoura, J.S., Serpa, C. \& Weschenfelder, J. 2018. Bathymetry estimation by orbital data of OLI sensor: A case study of the Rio Grande Harbor, Southern
Brazil. Journal of Coastal Research, 85: 51-55.

Alves, D.C.L., Espinoza, J.M.A., Albuquerque, M.G., Gonzaga, B.A., Westphlaen, A.B. \& Weschenfelder, J. 2019. Modelo topobatimétrico da desembocadura da Lagoa dos Patos e planície costeira adjacente (Brasil) obtido através de dados dos sensores ALOSPRISM e LANDSAT 8-OLI. Saindo da Zona de Conforto: A Interdisciplinaridade das Zonas Costeiras - Tomo VIII da Rede BRASPOR, p. 454-463.

Andersen, T.J., Lund-Hansen, L.C., Pejrup, M., Jensen, K.T. \& Mouritsen, K.N. 2005. Biologically induced differences in erodibility and aggregation of subtidal and intertidal sediments: a possible cause for seasonal changes in sediment deposition. Journal of Marine Systems, 55: 123-138.

Anderson, M.J., Gorley, R.N. \& Clarke, K.R. 2008. PERMANOVA + for PRIMER: Guide to Software and Statistical Methods. PRIMER-E: Plymouth, UK.

Antiqueira, J.A.F. \& Calliari, L.J. 2005. Características sedimentares da desembocadura da Laguna dos Patos. Gravel, 3: $39-46$.

Avramidis, P., Bouzos, D., Antoniou, V. \& Kontopoulos, N. 2008. Application of grain size trend analysis and spatio-temporal changes of sedimentation, as a tool for lagoon management. Case study: the Kotychi lagoon (western Greece). Geologica CarpathicaBratislava, 59: 261-268.

Baisch, P.R. \& Wasserman, J.C. 1998. Chemistry and distribution of trace elements in the Patos Lagoon, South Brazil. In: Wasserman J.C., Silva-Filho E.V. \& Villas-Boas R. (Eds) Environmental geochemistry in the tropics. Lecture Notes in Earth Sciences, vol 72. Springer Berlin Heidelberg, p. 97-126.

Balamurugan, P., Vasudevan, S., Selvaganapathi, R. \& Nishikanth, C.V. 2014. Spatial Distribution of Grain Size Characteristics and its Role in Interpreting the Sedimentary Depositional Environment, Kodaikanal Lake, Tamil Nadu, India. Journal of Earth Science \& Climatic Change, 5: 1000217.

Barros, G.P., Marques, W.C. \& Kirinus, E.P. 2014. Influence of the freshwater discharge on 
the hydrodynamics of Patos Lagoon, Brazil. International Journal of Geosciences, 5: 925942.

Barroso, H.S., Becker, H. \& Melo, V.M.M. 2016 Influence of river discharge on phytoplankton structure and nutrient concentrations in four tropical semiarid estuaries. Brazilian Journal of Oceanography, 64: 37-48.

Bemvenuti, C.E. \& Netto, S.A. 1998. Distribution and Seasonal patterns of the sublittoral benthic macrofauna of Patos Lagoon (South Brazil). Revista Brasileira de Biologia, 5: $211-$ 221.

Bitencourt, V.J.B. \& Dillenburg, S.R. 2020. Aplication of multivariate techniques in alongshore differenciation of coastal barriers. Marine Geology, 419: 106077.

Bragadeeswaran, S., Rajasegar, M., Srinivasan, M. \& Rajan, U.K. 2007. Sediment texture and nutrients of Arasalar estuary, Karaikkal, southeast coast of India. Journal of Environmental Biology, 28: 237-240.

Camargo, M.G. 1999. SysGran: um sistema de código aberto para análises granulométricas do sedimento. Revista Brasileira de Geociências, 36: 371-378.

Colling, L.A., Bemvenuti, C.E. \& Gandra, M.S. 2007. Seasonal variability on the structure of sublittoral macrozoobenthic association in the Patos Lagoon estuary, southern Brazil. Iheringia Série Zoologica, 97: 257-262.

Colling, L.A., Bemvenuti, C.E. \& Pinotti, R.M. 2010. Temporal variability of the bivalve Erodona mactroides BOSC, 1802 during and after El Niño phenomenon (2002/2003) in a subtropical lagoon, southern Brazil. Acta Limnologica Brasiliensia, 22: 410-423.

Cooper, J.A.G. 2002. The role of extreme floods in estuary-coastal behaviour: contrasts between river-and tide-dominated microtidal estuaries. Sedimentary Geology, 150: 123-137.

Costa, M.S.; Rocha, A.S.; Santos, A.S., \& Rolnic, M. 2018. Influence of tide on salt entrapment in the River Mojuim Estuary. Journal of Coastal Research, 85: 81-86.

Dyer, K.R., Christie, M.C., Feates, N., Fennessy, M.J., Pejrup, M. \& Van Der Lee, W. 2000. An investigation into processes influencing the morphodynamics of an intertidal mudflat, the Dollard Estuary, The Netherlands: I. Hydrodynamics and suspended sediment. Estuarine Coastal and Shelf Science, 50: 607625.

Fang, X., Mestdagh, S. Ysebaert, T., Moens, T., Soetaert, K. \& Colen, C.V. 2019. Spatiotemporal variation in sediment ecosystem processes and roles of key biota in the Scheldt estuary. Estuarine, Coastal and Shelf Science, 222: 21-31.

Fernandes, E.H.L., Dyer, K.R., Moller, O.O. \& Niencheski, L.F.H. 2002. The Patos Lagoon hydrodynamics during an El Niño event (1998). Proceedings from the Tenth Biennial Conference on the Physics of Estuaries and Coastal Seas, 22: 1699-1713.

Fernandes, E.H.L., Dyer, K.R. \& Moller, O.O. 2005. Spatial gradients in the flow of Southern Patos Lagoon. Journal of Coastal Research, 214: 759-769.

Folk, R.L. \& Ward, W.C. 1957. Brazos River bar, a study in the significance of grain size parameters. Journal of Sedimentary Petrology, 273-27.

Friedman, G.M. 1961. Distinction between dune, beach, and river sands from their textural characteristics. Journal of Sedimentary Research, 31: 514-529.

Grasso, F. \& Le Hir, P. 2019. Influence of morphological changes on suspended sediment dynamics in a macrotidal estuary: diachronic analysis in the Seine Estuary (France) from 1960 to 2010. Ocean Dynamics, 69: 83-100.

Ha, H.K. \& Park, K. 2012. High-resolution comparison of sediment dynamics under different forcing conditions in the bottom boundary layer of a shallow, micro-tidal estuary: Sediment dynamics in a shallow estuary. Journal of Geophysical Research: Oceans, 117: C06020

Hallermeier, R. 1981. A profile zonation for seazonal sand beaches from wave climate. Coastal Engineering, 4253-277.

Hillman, J.R., Stephenson, F., Thrush, S. \& Lundquist, C.J. 2020. Investigating changes in estuarine ecosystem functioning under future scenarios. Ecological Applications, 30(4): e02090. 
Hirata, F.E., Möller, O.O. \& Mata, M.M. 2010. Regime shifts, trends and interannual variations of water level in Mirim Lagoon, southern Brazil. Pan-Americam Journal of Aquatic Science, 5: 254-266.

Huang, W., Zhang, H., Zhu, L., Chen, L., Zhang, G., Wong, W. \& Liu, J. 2020. In-situ study of the spatiotemporal variability of sediment erodibility in a microtidal estuary. Estuarine, Coastal and Shelf Science, 232: 106530.

Jung, B.M. 2017. Variabilidade dos fluxos de sedimentos para a Lagoa dos Patos e os processos de trocas com o oceano adjacente. Rio Grande, 78p. Dissertação de Mestrado, Programa de Pós-graduação em Oceanografia Física, Química e Geológica, Universidade Federal do Rio Grande.

Kamaruzzaman, B.Y., Shazili, N.A.M. \& Mohd Lokman, H. 2002. Particle size distribution in the bottom sediments of the Kemaman River estuarine system, Terengganu, Malaysia. Pertanika Journal of Tropical Agricultural Science, 25: 149-156.

Karikalan, R., Sathasivam, R. \& Rakkiannan, S. 2020. Spatial grain size distribution of beach and Gundar River Estuary sediments of Mookaiyur, Gulf of Mannar coast, Ramanathapuram District, Tamilnadu, India. Infokara Research, 9: 209-217.

Kjerfve, B. 1986. Comparative oceanography of coastal lagoons. In: Wolfe, D.A. (Ed.) Estuarine Variability. London Academic Press, p. 63-81.

Kornman, B.A. \& De Deckere, E.M. 1998. Temporal variation in sediment erodibility and suspended sediment dynamics in the Dollard estuary. Geological Society, London, Special Publications, 139: 231-241.

Kumar Maity, S. \& Maiti, R. 2018. Analysis of bed load sediment texture. In Sedimentation in the Rupnarayan River. Springer International Publishing, p. 61-76

Manning, A.J., Langston, W.J. \& Jonas, P.J.C. 2010. A review of sediment dynamics in the Severn Estuary: Influence of flocculation. Marine Pollution Bulletin, 61: 37-51.

Marangoni, J.C. \& Costa, C.S.B. 2009. Natural and anthropogenic effects on salt marsh over five decades in the Patos Lagoon (Southern Brazil). Brazilian Journal of Oceanography, 57:
$345-350$.

Martelo, A.F., Trombetta, T.B., Lopes, B.V. Marques, W.C., Möller, O.O. 2019. Impacts of dredging on the hydromorphodynamics of the Patos Lagoon estuary, Southern Brazil. Ocean Engineering, 188: 106325.

Möller, O.O., Lorenzzetti, J.A., Stech, J.L. \& Mata, M.M. 1996. The summer time circulation and dynamics of Patos Lagoon. Continental Shelf Research, 16: 355-351.

Möller, O.O. \& Castaing, P. 1999. Hydrological characteristics of the estuarine area of Patos Lagoon (30S, Brazil). In: Perillo, G.M.E, Piccolo, M.C., Pino-Quivira, M. (Eds.). Estuaries of South America: their geomorphology and dynamics. Berlin, Springer-Verlag, p. 83-100.

Möller, O.O., Castaing, P., Salomon, J.-C. \& Lazure, P. 2001. The influence of local and non-local forcing effects on the subtidal circulation of Patos Lagoon. Estuaries, 24: 297-311.

NASA GES DISC (Data can be reproduced following the link https://giovanni.gsfc. nasa.gov/giovanni/\#service=ArAvTs\&startti me $=1997-01-01$ T00:00:00Z\&endtime $=2017-$ 09-30T23:59:59Z\&shape $=$ gpmLandMask / shp_0\&bbox $=-54.8437,-32.2998,-50.0537,-$ 28.96\&data=M2TMNXFLX_5_12_4_T(units $\% 3 \mathrm{Dmm} \% 2 \mathrm{Fmonth}) \&$ variableFacets=data FieldMeasurement\%3APrecipitation\%3B\&portal=GIOVANNI\&format=json)

Ortega, I., Colling, L.A. \& Dumont, L.F.C. 2018. Response of soft-bottom macrobenthic assemblages to artisanal trawling fisheries in a subtropical estuary. Estuarine, Coastal and Shelf Science, 207: 142-153.

Pereira, P.S., Calliari, L.J. \& Barletta, R.C. 2010. Heterogeneity and homogeneity of Southern Brazilian beaches: A morphodynamic and statistical approach. Continental Shelf Research, 30: 270-280.

Pino, M., Busquets, T. \& Brümmer, R. 1999. Temporal and spatial variability in the sediments of a tidal flat, Queule River Estuary, south-central Chile. Revista geológica de Chile, 26: 187-204.

Pruthivraj, T., Vasudevan, S., Balamurugan, P., Singhal, R.K., Selvaganapathi, R., Srinivasan, S., \& Nishikanth, C.V. 2013. Spatial distribution and temporal variations in the textural 
characteristics of the Veeranam lake sediments, Cuddalore district, Tamil Nadu. International Journal of Recent Scientific Research, 4: 949 - 955.

R Core Team. 2017. R: A language and environment for statistical computing. $R$ Foundation for Statistical Computing, Vienna, Austria. URL https://www.R-project.org/.

Rosa, L.C. Da \& Bemvenuti, C.E. 2004. Infaunal recruitment patterns in soft bottom habitats of the Patos Lagoon estuary, Southern Brazil: influence of Chasmagnathus granulata (Brachyura, Grapsidae) disturbance. Iheringia Série Zoologica, 94: 301-305.

Rosa, L.C. Da \& Bemvenuti, C.E. 2006. Temporal variability of the estuarine macrofauna of the Patos Lagoon, Brazil. Revista de Biología Marina y Oceanografía, 41: 1-9.

Santos, I.R., Baisch, P., Lima, G., Mirlean, N., Griep, G. \& Silva-Filho, E.V. 2004. Análise estatística multivariada de parámetros geoquímicos em sedimentos do estuário da Laguna dos Patos. Geochimica Brasiliensis, 18: 38-45.

Scotta, F.C. 2018. A hidrodinâmica e sedimentologia do rio Guaíba analisados por sensores geoacústicos e orbitais. Porto Alegre, 127 p. Tese de Doutorado, Programa de Pós-graduação em Geociências, Instituto de Geociências, Universidade Federal do Rio Grande do Sul.

Sedano, F., Marquina, D. \& Espinosa, F. 2014. Depth and sediment granulometry effects on subtidal meiofaunal assemblages of the subtropical coast of Granada (Alboran Sea). Zoologica Baetica, 25: 13-30

Shepard, F.P. 1954. Nomenclature based on sand-silt-clay ratios. Journal Sedimentary Petrology, 24: 151-158.

Siegle, E., Schettini, C.A., Klein, A.H. \& Toldo Jr, E.E. 2009. Hydrodynamics and suspended sediment transport in the Camboriú estuaryBrazil: pre jetty conditions. Brazilian Journal of Oceanography, 57: 123-135.

Souza, S.R. \& Hartmann, C. 2008. Modificação marginal das ilhas estuarinas usando ferramentas de aerofotogrametria, sedimentologia e batimetria. Revista Brasileira de Cartografia, 60: 307-318.

Souza, S.R., Oliveira, A.O. \& Hartmann, C. 2008.
Utilização do Testemunhador Rusian Peat Borer no Saco do Martins e Arraial, Estuário da Laguna dos Patos: RS, Brasil. Gravel, 6: 1-13. Suguio, K. 1973. Introdução a sedimentologia. São Paulo. Blücher, 370p.

Temmerman, S., Govers, G. \& Wartel, S. 2003. Spatial and temporal factors controlling shortterm sedimentation in a salt and freshwater tidal marsh, Scheldt estuary, Belgium, SW Netherlands. Earth Surface Process and Landforms, 28: 739-735.

Toldo Jr. E., S. Dillenburg, I. Corrêa, L. Almeida, J. Weschenfelder \& Gruber, N. 2007. Sedimentação de longo e curto período na Lagoa dos Patos, Sul do Brasil. Pesquisas em Geociências, 33(2): 79-86.

Tomazelli, L.J. \& Villwock, J.A. 2000. O cenozóico costeiro do Rio Grande do Sul. In: Holz, M. \& De Ros, L.F. (Eds) Geologia do Rio Grande do Sul. Porto Alegre, Edição CIGO/UFRGS, p. 375406.

Tomazelli, L.J., Dillenburg, S.R. \& Villwock, J.A. 2000. Late Quaternary geological history of Rio Grande do Sul coastal plain, southern Brazil. Revista Brasileira de Geociências, 30(3): 474-476.

Tudurí, A., Bergamino, L., Violante, R., Cavallotto, J.L. \& García-Rodríguez. F. 2018. Spatial and temporal variation in the present and historical sedimentary organic matter within the Río de la Plata estuary (South America) in relation to the salinity/turbidity gradient. Journal of Sedimentary Environments, 3(4): 265-279.

Van Der Wal, D., Van Kessel, T., Eleveld, M.A. \& Vanlede, J. 2010. Spatial heterogeneity in estuarine mud dynamics. Ocean Dynamics, 60: 519-533.

Vieira, H.M., Weschenfelder, J., Fernandes, E.H., Oliveira, H.A., Möller, O.O. \& GarcíaRodríguez, F. 2020. Links between surface sediment composition, morphometry and hydrodynamics in a large shallow coastal lagoon. Sedimentary Geology, 398: 105591.

Viitak, M., Maljutenko, I., Alari, V., Suursaar, U., Rikka, S. \& Lagemaa, P. 2016. The impact of surface currents and sea level on the wave field evolution during St. Jude storm in the eastern Baltic Sea. Oceanologia, 58: 176-186. Villwock, J.A. 1972. Contribuição à Geologia do 
Holoceno da Província Costeira do Rio Grande do Sul. Porto Alegre, 113 p. Dissertação de Mestrado, Programa de Pós-graduação em Geociências, Instituto de Geociências, Universidade Federal do Rio Grande do Sul.

Wallner-Kersanach, M., Mirlean, N., Baumgarten, M. Da G.Z., Costa, L.D.F. \& Baisch, P. 2016. Temporal evolution of the contamination in the southern area of the Patos Lagoon estuary, RS, Brazil. Revista de Gestão Costeira Integrada, 16: 263-279.

Widdows, J. \& Brinsley, M. 2002. Impact of biotic and abiotic processes on sediment dynamics and the consequences to the structure and functioning of the intertidal zone. Journal of Sea Research, 48: 143-156.

Widdows, J., Brinsley, M.D., Salkeld, P.N. \& Lucas, C.H. 2000. Influence of biota on spatial and temporal variation in sediment erodability and material flux on a tidal flat (Westerschelde, The Netherlands). Marine Ecology Progress Series, 194: 23-37.

Widdows, J., Blauw, A., Heip, C.H.R., Herman, P.M.J., Lucas, C.H., Middelburg, J.J., Schmidt, S., Brinsley, M.D., Twisk, F. \& Verbeek, H. 2004. Role of physical and biological processes in sediment dynamics of a tidal flat in Westerschelde Estuary, SW Netherlands. Marine Ecology Progress Series, 274: 41-56.

Yang, S.L., Li, H., Ysebaert, T., Bouma, T.J., Zhang, W.X., Wang, Y.Y., Li, P., Li, M. \& Ding, P.X. 2008. Spatial and temporal variations in sediment grain size in tidal wetlands, Yangtze Delta: On the role of physical and biotic controls. Estuarine, Coastal and Shelf Science, 77: 657671.

Ye, F., Guo, W., Shi, Z., Jia, G. \& Wei, G. 2017. Seasonal dynamics of particulate organic matter and its response to flooding in the Pearl River Estuary, China, revealed by stableisotope $\left(\delta^{13} \mathrm{C}\right.$ and $\left.\delta^{15} \mathrm{~N}\right)$ analyses, Journal of Geophysical Research: Oceans, 122: 6835-6856.

Manuscrito 101938 | Recebido em abr. de 2020 | Aceito em ago. de 2020 | Editor: Eduardo G. Barboza 